\title{
BOUNDED INQUIRY LABORATORY TERHADAP KEMAMPUAN LITERASI SAINS MAHASISWA
}

\author{
Muhammad Nasir ${ }^{1}$ \\ Erviana Abdullah ${ }^{2}$ \\ ${ }^{1}$ Pendidikan Biologi STKIP Puangrimaggalatung Sengkang \\ 2 Administrasi Pendidikan STKIP Puangrimaggalatung Sengkang \\ E-mail: muh.nasir250@gmail.com
}

\begin{abstract}
The aims of this research is to know the effectiveness of a model bounded inquiry laboratory to improve the ability of science literacy lecture a student on human anatomy and physiology. The research uses method is quasi-experiment, with his subjects the research uses two study groups namely in the first half of iv class A and B course biology education of STKIP Puangrimaggalatung Sengkang academic year 2017 / 2018. One class as a class experiment the classroom used the model bounded inquiry laboratory and other a class as a class control the classroom with learning directly or lectures. The data collection was done using a test of about literacy science. The result showed that model bounded inquiry laboratory with the sig .0,027; 0,05 and it so that it can be stated that guided inquiry-based learning more effective in upgrading literacy student than traditional learning lecture or lectures on human anatomy and physiology.
\end{abstract}

Key word: Bounded inquiry laboratory, human anatomy and physiology, literacy science

Literasi sains penting dikuasai oleh peserta didik berkaitan dengan bagaimana peserta didik memahami lingkungan hidup, kesehatan, ekonomi, dan masalahmasalah lain yang dihadapi masyarakat modern yang sangat bergantung pada kemajuan IPTEK (Yusuf, 2003). Organization for Economic Cooperation Development (OECD) (2012) menyatakan pengembangan literasi sains menyangkut tiga dimensi yaitu: dimensi konten, dimensi proses, dan dimensi konteks. Dimensi konten sains merujuk pada konsep-konsep kunci dari sains yang diperlukan untuk memahami fenomena alam. Dimensi proses merujuk pada proses mental yang terlibat ketika menjawab suatu pertanyaan atau memecahkan masalah. Dimensi konteks sains merujuk pada situasi dalam kehidupan sehari-hari yang menjadi lahan aplikasi proses dan pemahaman konsep sains.

Kenyataannya penguasaan literasi sains peserta didik Indonesia masih jauh dari harapan. Rendahnya kemampuan literasi sains peserta didik dalam bidang IPA terbukti dari hasil survei Programme for Internasional Students Assesment (PISA) tahun 2000 menunjukkan bahwa literasi sains peserta didik Indonesia peringkat ke-38 dari 41 negara peserta. Tahun 2003 menunjukkan bahwa literasi sains peserta didik Indonesia peringkat ke38 dari 40 negara peserta. Tahun 2006 peringkat ke-50 dari 57 negara peserta. Tahun 2009 peringkat ke-60 
dari 65 negara peserta. Tahun 2012 menduduki peringkat ke-64 dari 65 negara peserta. Berdasarkan hasil tes literasi sains PISA tahun 2012 diperoleh presentase sebesar 29\% dimensi konten, $32 \%$ dimensi proses, dan 34\% dimensi konteks (OECD, 2014). Hal tersebut menunjukkan bahwa tingkat pencapaian literasi sains peserta didik Indonesia masih dalam level rendah atau pada kemampuan menghafal. Menurut PISA literasi sains mengukur tiga kompetensi yang didasarkan pada logika, penalaran dan analisis kritis. Tiga kompetensi tersebut adalah mahasiswa mampu mengidentifikasi isu-isu (masalah) sains, menjelaskan fenomena-fenomena secara ilmiah, dan menggunakan buktibukti ilmiah.

$$
\text { Salah satu model }
$$

pembelajaran yang berpotensi untuk menyelesaikan permasalahan yang diuraikan sebelumnya adalah penerapan model Bounded Inquiry Laboratory. Masing-masing tahapan model pembelajaran inkuiri memiliki karakteristik yang berbeda-beda sesuai tingkat kecerdasan peserta didik dan pihak pengontrol. Peserta didik dengan kemampuan intelektual di jenjang SMA dan Universitas lebih sesuai menggunakan level Inquiry Laboratory hingga Hypothetical Inquiry. Level Inquiry Laboratory dibedakan menjadi tiga, yaitu: Guided Inquiry Laboratory, Bounded Inquiry Laboratory, dan Free Inquiry Laboratory. Bounded Inquiry Laboratory mampu meningkatkan kemampuan dan kemandirian peserta didik dalam merancang dan mengadakan eksperimen tanpa banyaknya panduan dari guru. Model Bounded Inquiry Laboratory menekankan pula kegiatan pre-lab yang jelas, sehingga keselamatan lab saat melakukan eksperimen dapat terjamin karena kegiatan prelab merupakan dasar untuk peserta didik melakukan praktikum.

Wenning (2010) dalam jurnalnya "Levels of Inquiry: Using inquiry spectrum learning sequences to teach science" memperkenalkan sebuah model pembelajaran berbasis inkuiri yang dikenal dengan model pembelajaran Hierarki of Inquiry atau level kegiatan inkuiri. Wenning mengelompokkan kesulitan menerapkan inkuiri dalam lima level, antara lain: discover learning, interactive demonstration, inquiry lesson, inquiry lab dan hypothetical inquiry. Kelima level pembelajaran inkuiri tersebut diurutkan berdasarkan kecerdasan intelektual peserta didik dan pihak pengontrol. Urutan pelaksanaan pembelajaran inkuiri menurut wenning seperti dijelaskan diatas yaitu bergerak dari arah kiri ke kanan, dari discover learning ke hypothetical inquiry.

Alternatif model pembelajaran yang berpotensi untuk menyelesaikan permasalahan literasi adalah model pembelajaran Bounded Inquiry Laboratory (BIL). Level BIL merupakan tahapan selanjutnya dari model pembelajaran level of inquiry dan merupakan tahap kedua dari aktivitas laboratorium (Inquiry 
Laboratorium). Peningkatan pada tahap ini ialah pada kemampuan dan kemandirian peserta didik dalam merancang dan mengadakan eksperimen tanpa banyaknya panduan dari guru serta adanya pre$l a b$ yang jelas. Pada level ini guru tidak banyak memberikan pertanyaan panduan, dan untuk kegiatan pre-lab lebih mengutamakan pada aspek eksperimental seperti keselamatan lab serta penggunaan perlindungan peralatan lab (Purwanto dkk, 2013). Solusi tersebut dikuatkan oleh penelitian yang dilakukan oleh Wenning (2010) yang menyatakan bahwa peserta didik dengan kemampuan intelektual di jenjang SMA dan perguruan tinggi lebih sesuai menggunakan level Inquiry Laboratory (Guided Inquiry Laboratory, Bounded Inquiry Laboratory dan Free Inquiry Laboratory) hingga level Hypothetical Inquiry.

Karakteristik indikator inquiry dari bounded inquiry laboratory (lab) adalah kegiatan prelab yang jelas dan teacher leading questioning. Kegiatan prelab difokuskan pada keselamatan kerja dan keamanan penggunaan alat laboratorium (Wenning, 2011). Teacher leading questioning merupakan kegiatan berupa pertanyaan yang diberikan guru tidak secara langsung menuntun peserta didik untuk membuat prosedur. Kelebihan indikator inquiry dari bounded inquiry laboratory (lab) adalah mampu melatih peserta didik menyelesaikan permasalahan secara mandiri dengan kegiatan prelab tanpa banyak panduan dari guru melalui kemampuan menyelidiki. Relevan dengan hasil penelitian Purwanto, dkk. (2013) bahwa kemampuan inquiry dapat diakses melalui kemampuan penyelidikan yang merupakan aspek proses sains, sehingga pembelajaran lebih bermakna dan mampu meningkatkan aspek literasi.

Berdasarkan penelitian yang dilakukan Nehru \& Syarkowi (2017) tentang analisis desain pembelajaran untuk meningkatkan literasi sains mahasiswa memiliki profil kongkret, dan memiliki kemampuan berpikir konservatif yang lebih baik dari kemampuan yang lain, sehingga dapat disimpulkan desain pembelajaran yang tepat adalah pembelajaran berbasis konstruktivisme dan menggunakan model pembelajaran inkuiri tingkat rendah atau proyek dengan bantuan (bimbingan). dan penelitian yang dilakukan oleh Susanto, Suciati dan Nurmiyati (2015) tentang penerapan bounded inquiry laboratory untuk meningkatkan tentang penerapan bounded inquiry laboratory untuk meningkatkan keterampilan proses sains disimpulkan bahwa penerapan model pembelajaran bounded inquiry laboratory dapat meningkatkan keempat aspek KPS peserta didik.

\section{METODE}

STKIP Puangrimaggalatung Sengkang Program Studi Pendidikan 
Biologi semester genap tahun akademik 2017/2018. Populasi dari penelitian adalah seluruh mahasiswa semester IV yang terbagi dalam dua rombongan belajar yaitu kelas A dan B dan sampel yang diambil terdiri dari dua kelas yang berbeda merupakan kelas kontrol yang tidak diberikan perlakuan dengan model pembelajaran bounded inquiry laboratory tetapi dengan metode konvensional, sedangkan yang merupakan kelas eksperimen yang pada pembelajarannya diterapkan model pembelajaran bounded inquiry laboratory. Kelas kontrol menggunakan metode konvensional karena pada prakteknya memang pembelajaran matakuliah diajarkan menggunakan metode ini. Penentuan sampling menggunakan purposive sampling dengan pertimbangan bahwa mahasiswa tersebut belum pernah memperoleh materi, memiliki kemampuan yang lebih dibandingkan kelas lainnya dan dapat memberikan informasi yang representatif dalam membantu hasil penelitian.

Metode yang digunakan dalam penelitian ini adalah eksperimen semu (QuasiExperimental), karena kelompok kontrol maupun eksperimen dipilih tidak secara random. Pada kelas kontrol pembelajaran yang diterapkan adalah metode konvensional sedangkan pada kelas eksperimen, metode yang digunakan adalah model pembelajaran inquiry lab dengan tipe bounded inquiry laboratory. Desain penelitian yang dipilih adalah Nonrandomized
Control Group, Pretest-Posttest

Design. Dalam rancangan ini digunakan dua kelompok subjek, yaitu kelompok kontrol dan eksperimen yang dipilih tidak secara random, keduanya diberikan pretest dan posttest (Ary dkk, 2010).

Data

dikumpulkan menggunakan lembar soal. Soal yang diberikan berupa soal pretest dan posttest. Soal tersebut diberikan kepada kelompok kontrol maupun eksperimen tentang literasi. Soal yang digunakan baik dalam pretest maupun posttest untuk literasi sains sama dan konteks yang diambil adalah sistem kardiovaskuler dan keterlaksanaan sintaks pembelajaran bounded inquiry laboratory dinilai selama pembelajaran berlangsung. Soal pretest diberikan sebelum pembelajaran berlangsung, baik untuk kelas kontrol maupun

eksperimen dan soal posttest diberikan setelah pembelajaran berlangsung baik untuk kelas kontrol maupun eksperimen.

Instrumen kemampuan literasi sains mengacu pada contoh instrumen yang diselenggarakan oleh PISA dalam Take The Test Sample Questions From OECD's PISA, peneliti mengembangkan sendiri instrumen tes kemampuan literasi sains yang disesuaikan dengan konteks dan konten yang sudah dikenali mahasiswa tentang sistem kardiovaskuler.

Sebuah tes dapat dikatakan valid jika sesuai dengan keadaan senyatanya, artinya tes dapat tepat mengukur apa yang hendak diukur 
(Arikunto, 2010). Untuk menghitung validitas instrumen yaitu dengan cara menghitung koefisien validitas, menggunakan rumus korelasi Product Moment. Proses uji validitas dibantu dengan menggunakan software ANATESV4. Untuk melihat validitas dari setiap butir soal dilihat pada kolom korelasi. Kemudian nilai perhitungan

Selanjutnya sebuah tes dikatakan dapat dipercaya jika dapat memberikan hasil yang tetap walaupun tes tersebut diberikan secara berulang-ulang. Tes dikatakan reliable apabila hasil-hasil tes menunjukkan ketetapan, artinya, jika kepada mahasiswa-mahasiswa diberikan tes yang serupa pada waktu yang berbeda maka setiap mahasiswa akan tetap berada dalam urutan yang sama dalam kelompok (Arikunto, 2010). Proses uji reliabilitas dibantu dengan menggunakan software ANATESV4.

Teknik analisis data dalam penelitian ini adalah Uji prasayarat ini terdiri atas dua bagian yakni uji normalitas dan uji homogenitas. Kedua uji ini akan dilakukan melalui software statistik SPSS. Selanjutnya uji hipotesis yang dilakukan yakni melalui uji dua rata-rata serta membandingkan gain yang ternormalisasi yang diperoleh pada kelas kontrol dengan kelas eksperimen. Jenis uji dua rata-rata yang digunakan bergantung kepada skala pengukuran variabel, jenis hipotesis. Jika skalanya berupa skala numerik dan jenis hipotesisnya adalah komparatif dengan, membandingkan dua kelompok yang tidak berpasangan dengan jumlah data 30 dan data berdistribusi normal maka dilakukan uji parametrik yaitu uji $\mathrm{t}$ independen, namun jika data tidak berdistribusi normal maka dilakukan uji Mann-Whitney. Hipotesis dalam pengujian berikut ini adalah : $\mathrm{HO}=$ tidak terdapat perbedaan yang signifikan $\mathrm{H} 1=$ terdapat perbedaan yang signifikan Kriteria pengambilan keputusan adalah jika nilai signifikansi > 0,05 maka $\mathrm{H} 0$ diterima, jika nilai signifikansi < 0,05 maka H0 ditolak.

\section{HASIL DAN PEMBAHASAN}

Temuan kemampuan literasi sains mahasiswa pada kelompok eksperimen dan kelompok kontrol diperoleh dengan pemberian pretest dan posttest.

Tabel 1. Data Kemampuan Literasi Sains Mahasiswa

\begin{tabular}{cccc}
\hline \multirow{2}{*}{ No } & \multirow{2}{*}{ Kelas } & \multicolumn{2}{c}{ Rata-rata } \\
\cline { 3 - 4 } & & Pretest & Posttest \\
\hline 1 & Eksperimen & 28.77 & 78.77 \\
2 & Kontrol & 27.55 & 72.86 \\
\hline
\end{tabular}

Tabel 1 di atas menunjukkan rerata skor kemampuan literasi sains mahasiswa menggambarkan peningkatan skor kemampuan literasi sains pada kelas eksperimen dan kelas kontrol. Peningkatan kemampuan literasi sains mahasiswa pada kelompok eksperimen sebesar 50 sedangkan pada kelas kontrol sebesar 45,31. Hasil peningkatan pada kelompok eksperimen dan kelompok kontrol diperoleh berdasarkan perlakuan pre-test dan 
post-test. Perbedaan peningkatan literasi sains pada kelas eksperimen dan kelas kontrol dianalisis menggunakan uji-t sampel independen dengan program SPSS versi 16. Hipotesis penelitian dalam uji-t tersebut adalah sebagai berikut: HO : Tidak ada perbedaan signikan peningkatan literasi sains mahasiswa yang mengikuti pembelajaran bounded inquiry laboratory dengan mahasiswa yang mengikuti perkuliahan secara tradisional atau ceramah pada mata kuliah anatomi dan fisiologi manusia dengan materi sistem gerak.

H1: Ada perbedaan signikan peningkatan literasi sains mahasiswa yang mengikuti pembelajaran bounded inquiry laboratory dengan mahasiswa yang mengikuti perkuliahan secara tradisional atau ceramah pada mata kuliah anatomi dan fisiologi manusia dengan materi sistem gerak.

Hasil uji hipotesis kemampuan literasi sains kelas eksperimen dan kelas kontrol diketahui bahwa nilai Sig. sebesar 0,027. Nilai Sig. $0,027<0,05$ sehingga $\mathrm{H}_{0}$ ditolak dan $\mathrm{H}_{1}$ diterima. Maka dapat diketahui bahwa ada pengaruh pemberian perlakuan pembelajaran bounded inquiry laboratory terhadap literasi sains mahasiswa.

Analisis posttest yang dilakukan di kelompok eksperimen serta kelompok kontrol, terjadi peningkatan nilai rata-rata kemampuan literasi sains. Setelah diberi perlakuan pembelajaran bounded inuiry laboratory sebagian besar siswa berada pada tingkat literasi multidimensional dan konseptual. Tingkat literasi multidimensional merupakan tingkat literasi sains tertinggi dimana siswa mampu memberikan jawaban atas pertanyaan ilmiah dengan kemampuan analisis, sintesis, atau tingkat evaluasi sehingga jawaban siswa menunjukkan transformasi diluar yang disediakan buku teks, sedangkan tingkat konseptual merupakan tingkatan literasi dimana siswa mamu menghubungkan konsep sains dengan fenomena kehidupan sehari-hari (Bybee, 1997).

Literasi sains mahasiswa kelompok eksperimen termasuk pada kategori tinggi dan efektif dibandingkan kelompok kontrol. Model perkuliahann yang dilaksanakan pada proses belajar mengajar, yaitu model pembelajaran bounded inquiry laboratory. Proses pembelajaran bounded inquiry laboratory mengarahkan mahasiswa berperan aktif dimana setiap tahap kemampuan dan kemandirian peserta didik dalam merancang dan mengadakan eksperimen tanpa banyaknya panduan dari guru serta adanya pre-lab yang jelas. Dalam pelaksanakan perkuliahan mahasiswa melakukan investigasi menggunakan berbagai sumber belajar sehingga akan menstimulasi kemampuan literasi sains mereka yaitu kemampuan discover learning, interactive demonstration, inquiry lesson, inquiry lab dan hypothetical inquiry dari sebuah fenomena yang 
ia temui sehingga mahasiswa akan memahami pengaruh sains terhadap perkembangan teknologi dan implikasinya bagi kehidupan.

\section{KESIMPULAN}

Terdapat perbedaan signifikan peningkatan literasi sains pada mahasiswa yang mengikuti pembelajaran bounded inquiry laboratory dengan siswa yang mengikuti pembelajaran secara tradisional atau ceramah pada perkuliahan anatomi dan fisiologi manusia dengan tema sistem kardiovaskuler, terlihat dari nilai Sig. sebesar 0,027. Nilai Sig. 0,027 < 0,05 , sehingga dapat dinyatakan bahwa pembelajaran berbasis guided inquiry lebih efektif dalam meningkatkan kemampuan literasi mahasiswa.

\section{DAFTAR RUJUKAN}

Arikunto, S. 2010. Dasar - Dasar Evaluasi Pendidikan. Jakarta. Bumi Aksar.

Ary, D., L. C. Jacobs, \& C. K. Sorensen. 2010. Introduction to Research in Education. Wadsworth. Cengage Learning Bybee, R. 1997. Toward an understanding of scientific literacy. Dalam W. Graber \& C. Bolte (Eds.), Scientific literacy, p. 37-68. Kiel, Germany: Institute for Science Education (IPN).

Organization for Economic Cooperation Development (OECD) PISA. 2014. Science competencies for tomorrow's world. Paris. OECD.

Organization for Economic Cooperation Development (OECD) PISA. 2012. Assessment Framework Key Competencies In Reading ,mathematics and science. OECD.

Purwanto, W. Liliawati, \& R.Hidayat. 2013. Analisis Kemampuan Inkuiri dan Hasil Belajar Siswa Sekolah Menengah Pertama melalui Model Pembelajaran berbasis Model Hierarki Of Inquiry. Prosiding Pertemuan Ilmiah XXVII HFI Jateng \& DIY, Solo, 23 Maret 2013. ISSN: 08530823.

Nehru \& A. Syarkowi. 2017. Analisis Desain Pembelajaran untuk Meningkatkan Literasi Sains Berdasarkan Profil Penalaran Ilmiah. Wahana Pendidikan Fisika(WAPFI). Vol 2, No 1 (2017).

Sutanto A. V., Suciati, \& Nurmiyati. 2015. Penerapan Bounded Inquiry Laboratory Untuk Meningkatkan Keterampilan Proses Sainspeserta Didik Kelas XI MIA 2 SMA N 1 Sukoharjo. BIO-PEDAGOGI 4(2): 5 - 9, Oktober 2015.

Wenning, C. J. 2010. Levels of inquiry: Using inquiry spectrum learning sequences to teach science. Journal Physics Teacher of Education. 5(4) p.11-19. (2010). 
Wenning, C.J., 2011. The Levels of Inquiry Model of Science Teaching. Journal of Physics Teacher Education. Online, 6(2): p. 2-9. (2011). 